\title{
Effect of Various Disinfectants Used, on Resistant Bacteria in Our Hospital
}

\author{
Saliha Aydin ${ }^{1}$, Selma Karagoz ${ }^{2}$, Zeynep Ture Yuce ${ }^{3}$, Zehra Bestepe Dursun ${ }^{4}$, Ilhami Celik ${ }^{4}$ \\ ${ }^{1}$ Department of Public Health, Ankara University Faculty of Medicine, Turkey. ${ }^{2}$ Department of Medical \\ Microbiology, Kayseri State Hospital, Turkey. ${ }^{3}$ Department of Infectious Disease and Clinical Microbiology. \\ Erciyes University Faculty of Medicine, Turkey. ${ }^{4}$ Department of Infectious Disease and Clinical Microbiology, \\ Kayseri City Education and Research Hospital. Turkey.
}

\section{ABSTRACT}

\section{BACKGROUND}

We wanted to determine the sensitivity status of microorganisms isolated from our patients with regard to the various disinfectants used in our hospital.

\section{METHODS}

An in vitro study was performed. The sensitivity of microorganisms against disinfectants was studied by qualitative suspension method. In the study, it was planned to study the sensitivity status of Acinetobacter baumannii, Klebsiella pneumoniae, Pseudomonas aeruginosa, Staphylococcus aureus with regard to A (2propanol, ethanol, benzalkonium chloride, glucoprotamine), B $(0.55 \%$ orthophthalaldehyde), and C (5\% sodium hypochlorite) on using the following standard strains - S. aureus NCTC® 12493, A. baumannii ATCC $₫$ BAA 1605, K. pneumoniae ATCC $\AA 700603$, P. aeruginosa ATCC $\AA 27853$. Bacterial strains were prepared as per turbidity of $0.5 \mathrm{McF}$ arland standard. Microdilution was carried out with disinfectant solutions. Passages were made to the solid medium at the end of 1,5-, 10- and 20-minutes contact periods, respectively bacterial growth was evaluated.

\section{RESULTS}

A, B were effective at $5^{\text {th }}$ minute against hospital strains and standard bacterial strains. Two hospital strains of K. pneumoniae and one hospital strain of $P$. aeruginosa were detected at the first concentrated duration of $\mathrm{C}$. In addition, a hospital strain of $K$. pneumoniae culture positivity was detected at the $5^{\text {th }}$ and $10^{\text {th }}$ minute of contact.

\section{CONCLUSIONS}

According to results of the study, disinfection policy must be established in all hospitals so that patients can be protected from hospital infections. Each hospital needs to identify effective antiseptics / disinfectants against microbial flora isolated in their hospital.

\section{KEY WORDS}

Disinfection, Disinfectant Effectiveness, Qualitative Suspension Test, Nosocomial Infection
Corresponding Author: Dr. Saliha Aydin, Ankara University, Faculty of Medicine, Ankara, Turkey.

E-mail: saliha_meva@hotmail.com

DOI: $10.14260 /$ jemds/2021/16

How to Cite This Article:

Aydin S, Karagoz S, Ture Yuce Z, et al. Effect of various disinfectants used, on resistant bacteria in our hospital. J Evolution Med Dent Sci 2021;10(02):79-82, DOI: 10.14260/jemds/2021/16

Submission 12-08-2020,

Peer Review 13-11-2020,

Acceptance 20-11-2020,

Published 11-01-2021.

Copyright (C) 2021 Saliha Aydin et al. This is an open access article distributed under Creative Commons Attribution License [Attribution 4.0 International (CC BY 4.0)] 


\section{BACKGROUND}

Hospital-acquired infections are an important health problem in developing and developed countries. In $5-10 \%$ of the patients admitted to the hospital, a hospital-acquired infection is observed during their treatment. ${ }^{1}$ In recent years, hospitalacquired infections caused by multidrug-resistant bacteria increase morbidity and mortality in patients. The transmission of this microorganism is mostly by cross-carriage through the hands of people who are in close contact with the patient, such as healthcare professionals and their relatives. ${ }^{2}$

The source is hands of healthcare professionals in $20-40$ $\%$ of the transport and spread of microorganisms that show high transmission and multiple drug resistance within the hospital. Decreased compliance with hand hygiene causes changes in hospital flora, increase in hospital infections and emergence of new resistant microorganisms. ${ }^{3}$ Skin antiseptics used in hospitals are fast-acting and are as effective as handwashing in maintaining hand hygiene. ${ }^{4}$

The selection and use of appropriate disinfectants is one of the important steps in the prevention of nosocomial infections. For this reason, every hospital should know the sensitivity of microorganisms that causes the most problems to the disinfectants used..$^{5}$ It has been reported in the literature that bacteria develop resistance to phenol, alcohol, chlorine compounds. ${ }^{6,7}$

The sensitivity of microorganisms to disinfectants varies depending on their structural features. While natural resistance is generally related to the reduction of the disinfectant uptake into the cell; The acquired resistance develops through chromosomal mutations and plasmids. ${ }^{8}$ Tests measuring the effectiveness of disinfectants are divided into two groups according to the test structure: Disinfectant activity measurement tests; determination of minimal inhibitory concentration are suspension tests, capacity tests and application tests. Specific tests are aimed at measuring the effectiveness of surface disinfection, instrument disinfection, hand and skin antisepsis. Suspension tests are the most used, inexpensive, easy to apply and repeatable tests. ${ }^{9}$

In this study, the susceptibility and duration of action on 32 multi-drug resistant bacterial strains and 4 standard strain samples isolated from three disinfectants, which are frequently used in our hospital, were investigated.

\section{METHODS}

This in-vitro study was conducted in the Medical Microbiology Laboratory of Health Sciences University Kayseri Training and Research Hospital. Disinfectants used are presented in Table 1, The bacteria used are presented in Table 2. C disinfectant was used without diluting, $1 / 10$ diluted $(1 \mathrm{ml}$ disinfectant +9 $\mathrm{ml}$ distilled water) and $1 / 100$ diluted (1 ml disinfectant +99 $\mathrm{ml}$ distilled water). Final concentrations of neutralizing solution substances were prepared with $3 \%$ saponin, $0.1 \% \mathrm{~L}$ cysteine, $0.1 \%$ L- histidine, $3 \%$ Tween 80 with Tryptic Soy Broth (TSB). Sterilized in an autoclave at $121^{\circ} \mathrm{C}$ for 15 minutes. Culture procedures from blood samples and identification of microorganisms grown in culture were performed in the Microbiology Laboratory of our hospital. Strains detected in blood culture were further identified with
BD Phoenix automated system (Becton Dickinson USA). Strains identified and antibiotic susceptible according to EUCAST criteria were processed.

\begin{tabular}{|cc|}
\hline Disinfectants & \\
A (Incidin Foam ${ }^{\circledR}$ ) & 2 Propanol, Ethanol, Benzalkonium Chloride, Glucoprotamine \\
B (Cidex OPA ${ }^{\text {) }}$ & $0.55 \%$ Ortho-Phthalaldehyde \\
C (Power Clean $\left.{ }^{\circledR}\right)$ & $5 \%$ Sodium Hypochlorite \\
\hline \multicolumn{2}{|c|}{ Table 1. Disinfectants Used in the Study } \\
\hline
\end{tabular}

\begin{tabular}{|cc|}
\hline Bacteria & Number of Strain \\
\hline Acinetobacter baumannii & 8 \\
Klebsiella pneumoniae & 8 \\
Pseudomonas aeruginosa & 8 \\
Staphylococcus aureus & 8 \\
A. baumannii ATCC $®$ BAA- $1605^{\text {TM }}$ & 1 \\
K. pneumoniae ATCC $® 700603^{\text {TM }}$ & 1 \\
P. aeruginosa ATCC $® 27853^{\text {TM }}$ & 1 \\
S. aureus NCTC $® 12493$ & 1 \\
\hline Table 2. Bacteria Used in the Study and the Number of Strains \\
\hline
\end{tabular}

Sensitivity Study method: The effectiveness of disinfectants on resistant bacteria was done by the qualitative suspension method.10,11 36 bacteria used for the test were planted in TSA and incubated in the oven for 24 hours at $37^{\circ} \mathrm{C}$. Bacterial suspensions in 0.5 McFarland turbidity $\left(1.5 \times 10^{8}\right.$ CFU / mL: Colony Forming Unit / millilitre) were prepared with TSB, a 24-hour culture of microorganisms.

1000 microliters $(\mu \mathrm{L})$ of disinfectant to be tested for each bacterium were put into the tubes, $10 \mu \mathrm{L}$ of the bacterial suspension prepared in $0.5 \mathrm{McF}$ arland turbidity was added to these tubes and kept for 1-5-10-20 minutes. At the end of each period, $100 \mu \mathrm{L}$ of bacteria and disinfectant mixture is taken and added to the tubes containing $900 \mu \mathrm{l}$ of neutralizing agent, which were prepared separately for each working minute before; $10 \mu \mathrm{L}$ of this mixture was taken and inoculated to TSA.

Petri dishes were incubated at $37^{\circ} \mathrm{C}$ for 48 hours. For control cultivation, solutions without disinfectant were prepared and cultivated in petri dishes. Lack of reproduction at the end of periods was interpreted as disinfectant having a bactericidal effect.

\section{RESULTS}

Reproduction status of bacteria after contact times with disinfectants are shown in Table 4. Accordingly, in the disinfectant A, the growth of a hospital strain K. pneumoniae was observed during the first minute contact time. The disinfectant A was effective from all hospital strains and standard bacterial strains from the fifth minute.

At the end of the first minute contact to the B disinfectant, the growth of a hospital strain $K$. pneumoniae and a hospital strain A. baumannii was monitored. The B disinfectant was effective from the fifth minute against all hospital strains and standard bacterial strains.

When working without diluting to the $\mathrm{C}$ disinfectant, the growth of two hospital strains K. pneumoniae and one hospital strain $P$. aeruginosa were detected after the first minute of action. Also $5^{\text {th }}-10^{\text {th }}$ reproduction of a hospital strain $K$. pneumoniae with minute contact time was detected. In the 1 / 10 dilution of $\mathrm{C}$ disinfectant, two $A$. baumannii, three $K$. pneumoniae and one $P$. aeruginosa growth were observed in the hospital strains during the first minute action time. 


\begin{tabular}{|c|c|c|c|c|c|c|c|c|c|c|c|c|c|c|c|c|c|c|c|c|}
\hline \multirow[b]{2}{*}{ Time Bacteria } & \multicolumn{4}{|c|}{ A } & \multicolumn{4}{|c|}{ B } & \multicolumn{4}{|c|}{$\mathbf{C}$} & \multicolumn{4}{|c|}{ C $1 / 10$} & \multicolumn{4}{|c|}{ C $1 / 100$} \\
\hline & $\begin{array}{c}1 \\
\text { min }\end{array}$ & $\begin{array}{c}5 \\
\text { min }\end{array}$ & $\begin{array}{c}10 \\
\text { min }\end{array}$ & $\begin{array}{c}20 \\
\text { min }\end{array}$ & $\begin{array}{c}1 \\
\min \end{array}$ & $\begin{array}{c}5 \\
\min \end{array}$ & $\begin{array}{c}10 \\
\text { min }\end{array}$ & $\begin{array}{c}20 \\
\text { min }\end{array}$ & $\begin{array}{c}1 \\
\mathbf{m i n}\end{array}$ & $\begin{array}{c}5 \\
\text { min }\end{array}$ & $\begin{array}{c}10 \\
\text { min }\end{array}$ & $\begin{array}{c}20 \\
\text { min }\end{array}$ & $\begin{array}{c}1 \\
\min \end{array}$ & $\begin{array}{c}5 \\
\text { min }\end{array}$ & $\begin{array}{c}10 \\
\text { min }\end{array}$ & $\begin{array}{c}20 \\
\text { min }\end{array}$ & $\begin{array}{c}1 \\
\min \end{array}$ & $\begin{array}{c}5 \\
\min \end{array}$ & $\begin{array}{c}10 \\
\text { min }\end{array}$ & $\begin{array}{c}20 \\
\text { min }\end{array}$ \\
\hline A. baumannii ATCC $® B A A-1605^{\mathrm{TM}}$ & $\mathbf{0}$ & $\mathbf{0}$ & $\mathbf{0}$ & $\mathbf{0}$ & $\mathbf{0}$ & $\mathbf{0}$ & $\mathbf{0}$ & $\mathbf{0}$ & $\mathbf{0}$ & $\mathbf{0}$ & $\mathbf{0}$ & $\mathbf{0}$ & $\mathbf{0}$ & $\mathbf{0}$ & $\mathbf{0}$ & $\mathbf{0}$ & $\mathbf{0}$ & $\mathbf{0}$ & $\mathbf{0}$ & $\mathbf{0}$ \\
\hline K. pneumoniae ATCC $® 700603^{\mathrm{Tm}}$ & $\mathbf{0}$ & $\mathbf{0}$ & $\mathbf{0}$ & $\mathbf{0}$ & $\mathbf{0}$ & $\mathbf{0}$ & $\mathbf{0}$ & $\mathbf{0}$ & $\mathbf{0}$ & $\mathbf{0}$ & $\mathbf{0}$ & $\mathbf{0}$ & $\mathbf{0}$ & $\mathbf{0}$ & $\mathbf{0}$ & $\mathbf{0}$ & 1 & 1 & $\mathbf{0}$ & $\mathbf{0}$ \\
\hline MRSA NCTC@12493 & $\mathbf{0}$ & $\mathbf{0}$ & $\mathbf{0}$ & $\mathbf{0}$ & $\mathbf{0}$ & $\mathbf{0}$ & $\mathbf{0}$ & $\mathbf{0}$ & $\mathbf{0}$ & $\mathbf{0}$ & $\mathbf{0}$ & $\mathbf{0}$ & $\mathbf{0}$ & $\mathbf{0}$ & $\mathbf{0}$ & $\mathbf{0}$ & $\mathbf{0}$ & $\mathbf{0}$ & $\mathbf{0}$ & $\mathbf{0}$ \\
\hline P. aeruginosa ATCC $₫ 27853^{\mathrm{TM}}$ & $\mathbf{0}$ & $\mathbf{0}$ & $\mathbf{0}$ & $\mathbf{0}$ & $\mathbf{0}$ & $\mathbf{0}$ & $\mathbf{0}$ & $\mathbf{0}$ & $\mathbf{0}$ & $\mathbf{0}$ & $\mathbf{0}$ & $\mathbf{0}$ & $\mathbf{0}$ & $\mathbf{0}$ & $\mathbf{0}$ & $\mathbf{0}$ & $\mathbf{0}$ & $\mathbf{0}$ & $\mathbf{0}$ & $\mathbf{0}$ \\
\hline A. baumannii (8) & $\mathbf{0}$ & $\mathbf{0}$ & $\mathbf{0}$ & $\mathbf{0}$ & 1 & $\mathbf{0}$ & $\mathbf{0}$ & $\mathbf{0}$ & $\mathbf{0}$ & $\mathbf{0}$ & $\mathbf{0}$ & $\mathbf{0}$ & 2 & $\mathbf{0}$ & $\mathbf{0}$ & $\mathbf{0}$ & 6 & 3 & 2 & 1 \\
\hline K. pneumoniae (8) & 1 & $\mathbf{0}$ & $\mathbf{0}$ & $\mathbf{0}$ & 1 & $\mathbf{0}$ & $\mathbf{0}$ & $\mathbf{0}$ & 2 & 1 & 1 & $\mathbf{0}$ & 3 & 2 & 1 & 1 & 7 & 6 & 6 & 5 \\
\hline MRSA (8) & $\mathbf{0}$ & $\mathbf{0}$ & $\mathbf{0}$ & $\mathbf{0}$ & $\mathbf{0}$ & $\mathbf{0}$ & $\mathbf{0}$ & $\mathbf{0}$ & $\mathbf{0}$ & $\mathbf{0}$ & $\mathbf{0}$ & $\mathbf{0}$ & $\mathbf{0}$ & $\mathbf{0}$ & $\mathbf{0}$ & $\mathbf{0}$ & $\mathbf{5}$ & $\mathbf{5}$ & $\mathbf{5}$ & 4 \\
\hline P. aeruginosa (8) & $\mathbf{0}$ & $\mathbf{0}$ & $\mathbf{0}$ & $\mathbf{0}$ & $\mathbf{0}$ & $\mathbf{0}$ & $\mathbf{0}$ & $\mathbf{0}$ & 1 & $\mathbf{0}$ & $\mathbf{0}$ & $\mathbf{0}$ & 1 & $\mathbf{0}$ & $\mathbf{0}$ & $\mathbf{0}$ & 5 & 5 & 4 & 4 \\
\hline
\end{tabular}

In addition, two K. pneumoniae strains from the hospital strains and one $K$. pneumoniae growth were observed at the $10^{\text {th }}, 20^{\text {th }}$ minute contact time. From the bacteria studied at $1 /$ 100 dilution of $\mathrm{C}$ disinfectant, K. pneumoniae standard strain, six hospital strains $A$. baumannii, seven hospital strains $K$. pneumoniae, five hospital strains MRSA (Methicillin-Resistant Staphylococcus aureus) and five hospital strains P. aeruginosa growth were detected. During the fifth minute contact times, three hospital strains A. baumannii, six hospital strains $K$. pneumoniae, five hospital strains MRSA and five hospital strains $P$. aeruginosa growth were detected. During the tenth minute contact times, two hospital strains A. baumannii, six hospital strains K. pneumoniae, five hospital strains MRSA, four hospital strains $P$. aeruginosa growth were detected. Twentyminute contact times revealed growth of one hospital strain $A$. baumannii, five hospital strains $K$. pneumoniae, four hospital strains MRSA and four hospital strains $P$. aeruginosa.

\section{DISCUSSIONS}

According to surveillance data of our hospital, there were 326 bacteraemia cases in the Anaesthesia and Reanimation Intensive Care Unit in 2016. Reproductive contamination in sixty blood cultures, $52 \%$ of the 266 factors found growth in blood culture, gram negative, $44 \%$ gram-positive bacteria, 4 $\%$ yeast fungus reproduced. Gram negative bacteria were $A$. baumannii (47 \%), Klebsiella spp (23\%), P. aeruginosa (9 \%), respectively. Gram-positive bacteria are CNS (Central Nervous System) (62\%), Enterococcus spp (20\%), S. aureus (16\%).

The effectiveness of the disinfectant; Use according to the prospectus or non-prospectus changes, use with different concentrations, different contact times. ${ }^{12}$ Disinfection of the environment and materials with the right disinfectant and applications can prevent the emergence of the hospital infection. In order to achieve this result, it is necessary to demonstrate that disinfectant is effective against microorganisms that can be found in the hospital environment with reliable tests, and the application method and application concentrations can be determined accurately. ${ }^{13,14}$

Bleach contains $5.25 \%$ hypochlorite, i.e. 52,500 ppm free chlorine; Reconstitution of the bleach 1: 100 provides about $525 \mathrm{ppm}$ of free chlorine. CDC (Centers for Disease Control and Prevention) on non-porous surface, $<10 \mathrm{ml}$ splash: 1: 100 dilution (prepared with $5.25 \%$ sodium hypochlorite), > $10 \mathrm{~mL}$, if large splash or large lab-based splash; To reduce the risk of infection during the procedure, it is recommended to apply a 1:10 dilution before cleaning and terminal disinfection with a 1: 100 dilution after this decontamination. ${ }^{15}$
Sodium hypochlorite $(<5 \%$ ) used in our hospital, without dilution, showed that growths were detected in the patient isolates at the end of a 10-minute encounter, and that it was necessary to contact all bacteria for at least 20 minutes. It was observed that it was not effective in the contact periods followed in dilutions. There is a need for new research for this.

In another study, the direct and $1 / 10$ diluted form of sodium hypochlorite ( $5 \%$ ) was found to be effective from the 1st minute, and the growth was detected in both standard bacteria and patient isolates at 1 / 100 dilution after 2 minutes of exposure. It suggested that it should be applied for at least 5 minutes. ${ }^{11}$

In a similar study, the efficacy of five disinfectants (phenolic compounds, Didecyl-Dimethyl-Ammonium Chloride (DDAC), sodium hypochlorite, Isopropanol + Ammonium Compounds (IACs), hydrogen peroxide) against 187 bacterial strains containing clinical isolates and thirty P. aeruginosa strains taken from hospital water samples that were environmental isolates were examined. Hydrogen peroxide has been shown to be effective against both clinical and environmental strains. IAC and DDAC are only effective on gram positive bacteria; Sodium hypochlorite and phenol compounds were not effective on any strain. ${ }^{16}$

In another study, 20 P. aeruginosa, 20 Acinetobacter spp and $20 \mathrm{~K}$. pneumoniae strains reported as nosocomial infection agents were studied with sodium hypochlorite. The effects of sodium hypochlorite at $1 / 10,1 / 100$ and $1 / 1000$ dilutions were investigated after contact times of $1,2,5,10$ and 30 minutes. In sodium hypochlorite 1 / 10 dilution, growth was detected in Acinetobacter spp. in only 1 minute. Sodium hypochlorite was found effective in 1 / 100 dilution after 2 minutes of contact with $P$. aeruginosa, 5 minutes of contact with $K$. pneumoniae and 10 minutes of contact time with Acinetobacter.

\section{CONCLUSIONS}

As a result, it was determined that the disinfectants we used in our study had different effects against standard strains and hospital strains, and some of them did not have any effect. When choosing a disinfectant, selection should be made by considering factors such as toxicity, ease of use, storage conditions, stability, recommended use dilution, application time and price. In the selection of disinfectants in every hospital, disinfectants with questionable effects should be avoided, especially in the surface disinfection of critical equipment and high-risk areas. It will be more beneficial for each hospital to determine the effective disinfectants and 
antiseptics against its own microorganisms in preventing hospital infection.

\section{Limitations}

Advanced analysis for selected hospital strains is required. Use of quantitative testing would be more suitable for disinfectant effectiveness.

Data sharing statement provided by the authors is available with the full text of this article at jemds.com.

Financial or other competing interests: None.

Disclosure forms provided by the authors are available with the full text of this article at jemds.com.

\section{REFERENCES}

[1] Chakraborty B, Pal NK, Maiti PK, et al. Action of newer disinfectants on multidrug resistant bacteria. Journal of Evolution of Medical and Dental Sciences 2014;3(11):2797-813.

[2] Boyce JM, Pittet D. Guideline for Hand Hygiene in HealthCare Settings. Recommendations of the Healthcare Infection Control Practices Advisory Committee and the HICPAC/SHEA/APIC/IDSA Hand Hygiene Task Force. Society for Healthcare Epidemiology of America/Association for Professionals in Infection Control/Infectious Diseases Society of America. MMWR Recomm Rep 2002;51(RR-16):1-45.

[3] Alp E. Enfeksiyon Kontrol Programı. Yayın no: 55. Kayseri: Erciyes Üniversitesi Hastaneleri 2012.

[4] Babeluk R, Jutz S, Mertlitz S, et al. Hand Hygieneevaluation of three disinfectant hand sanitizers in a community setting. PLoS One 2014;9(11):e111969.

[5] Altındiş M, Fiçıcı SE, Çentinkol Y, et al. Povdon-yot, Klorhekzidin glukonat, gluteraldehid ve oktenidin hidrokloridin nosokomiyal Acinetobacter baumannii suşlarına etkinliği. ANKEM Derg 2004;18(2):97-100.
[6] Campos GB, Souza SG, Lobao TN, et al. Isolation, molecular characteristics and disinfection of methicillin-resistant Staphylococcus aureus from ICU units in Brazil. New Microbiol 2012;35(2):183-90.

[7] Chapman JS. Disinfectants resistance mechanisms, crossresistance, and co-resistance. Int Biodeterior Biodegrad 2003;51(4):271-6.

[8] Rutala AW, Weber DJ. Disinfection, sterilization, and control of hospital waste. In: Mandell GL, Bennett JE, Dolin $\mathrm{R}$, eds. Principles and practice of infectious diseases. $6^{\text {th }}$ edn. Philadelphia: Elsevier 2005:3331-47.

[9] Çağlar K. Dezenfektanların etkinliğini ölçen testlerin birbirlerine avantajları ve dezevantajları.Günaydın $M$, Sünbül M eds. 3. Sterilizasyon ve Dezenfeksiyon Kongresi Kongre Kitabında. Ankara: Bilimsel Tıp Yayınevi 2003:334-43.

[10] İrikli S, Tatman-Otkun M. Bazl antiseptik ve dezenfektanların in vitro antimikrobik aktivitelerinin araştırılması. İnfeksiyon Derg 2007;21(1):7-13.

[11] Avcı D, Otkun M. Bazı antiseptik ve dezenfektanların antibakteriyel etkinliklerinin araştırılması. Turk Hij Den Biyol Derg 2017;74(3):211-20.

[12] West AM, Teska PJ, Lineback CB, et al. Strain, disinfectant, concentration, and contact time quantitatively impact disinfectant efficacy. Antimicrob Resist Infect Control 2018;7:49.

[13] Darouiche RO, Wall MJ, Itani KMF, et al. Chlorhexidinealcohol versus povidone-iodine for surgical-site antisepsis. N Engl J Med 2010;362(1):18-26.

[14] Rutela WA, Weber DJ. Disinfection, sterilization, and control of hospital waste. In: Mandell GL, Bennett JE, Dolin $\mathrm{R}$, eds. Mandell, Douglas, and Bennett's principles and practice of infectious diseases. $8^{\text {th }}$ edn. Philadelphia, PA, USA: Churchill Livingstone 2015:3294-309.

[15] Rutela WA, Weber DJ. Guideline for disinfection and sterilization in healthcare facilities, 2008.

[16] Montagna MT, Triggiano F, Barbuti G, et al. Study on the in vitro activity of five disinfectants against nosocomial bacteria. Int J Environ Res Public Health 2019;16(11):1895. 